\title{
Los objetos con alma: legitimidad de la esclavitud en el discurso de Aristóteles y Alonso de Sandoval. Una aproximación desde la construcción del cuerpo
}

\author{
Catalina Ariza Montañez \\ Universidad Nacional de Colombia \\ catalina_ariza@yahoo.es
}

\begin{abstract}
Resumen
En este artículo se hace un estudio comparativo entre las obras de Aristóteles y del jesuita del siglo XVII, Alonso de Sandoval, en especial el Tractatus de Instauranda de Aethiopum Salute (1627), con el fin de comparar la concepción de la esclavitud que tenía este filósofo de la Grecia Antigua y los teólogos españoles del periodo colonial. Se toma como referente la construcción social y cultural del cuerpo, siguiendo las ideas propuestas por David Le Bretón. Se argumenta que desde la Antigüedad la legitimación de la esclavitud se basó en la idea de una inferioridad natural inscrita en los cuerpos de los esclavos. Esta aproximación corporal ayuda a dilucidar las redes de significación que dieron sentido a la esclavitud, permitiendo resaltar las diferencias, semejanzas, correlaciones, superposiciones, contradicciones en la obra de los dos autores.

Palabras clave: ARISTÓTELES, ALONSO DE SANDOVAL, ESCLAVITUD, CUERPO, SIGLO XVII.
\end{abstract}

\begin{abstract}
This article explores the work of Aristotle and Alonso de Sandoval, a 17th century Jesuit, specifically the latter's Tractatus de Instauranda de Aethiopum Salute (1627), in order to compare the concept of slavery held by this Greek philosopher with that of Spanish colonial theologians. Following David Le Bretón's ideas, the social and cultural construction of the body is used as a reference throughout the text. It is argued that since Antiquity, the legitimacy of slavery rested upon the idea of a natural inferiority inscribed in the body of slaves. Approaching this problem through the body helps elucidate the webs of meaning that gave sense to slavery, thus highlighting the differences, similarities, correlations, overlaps, and contradictions present in both authors.

Key words: ARISTOTLE, ALONSO DE SANDOVAL, SLAVERY, BODY, $17^{\mathrm{TH}}$ CENTURY.
\end{abstract}




\section{Introducción $^{1}$}

Pese a que algunos estudios han demostrado que la influencia de la escolástica en la teología cristiana fue más limitada de lo aceptado comúnmente ${ }^{2}$, es innegable que la obra de Aristóteles, y su lectura tomista, fue de uso obligado en la construcción ontológica del ser humano en el medioevo europeo y en la América colonial. Este es el caso de la idea de los bárbaros, seres humanos de condición corporal y metafísica inferior, cuyas conductas, maneras y costumbres eran consideradas como irracionales, y que fue argumento común en las discusiones sobre la naturaleza de las poblaciones no europeas. Asimismo lo fue la concepción de la esclavitud como condición natural e inherente de los pueblos inferiores, que permitió legitimar jurídica e ideológicamente la trata durante el medioevo europeo y la América colonial.

Para Davis ${ }^{3}$, el predominio de la autoridad del Estagirita en la cultura occidental como la denominó el mismo autor- influyó en que la esclavitud permaneciera en esencia invariable desde la Grecia antigua. Sin embargo, una aproximación semántica e interpretativa de carácter cultural -siguiendo la propuesta de Clifford Geertz ${ }^{4}$ - permite evidenciar sendas diferencias entre la esclavitud antigua ${ }^{5}$ y la que se dio en períodos posteriores. Conclusión a la que llegué luego del estudio comparativo realizado entre la obra de Aristóteles y la de Alonso Sandoval -cuyos resultados han sido consignados en este artículo-, donde se puede observar cómo el cristianismo supuso nuevas valoraciones de la esclavitud.

Probablemente, uno de los libros más interesantes sobre la esclavitud en la América española sea el Tractatus de Instauranda de Aethiopum Salute del padre

\footnotetext{
${ }^{1}$ El siguiente texto se deriva de mi trabajo de grado, titulado "Plantación adentro, camará: El cuerpo y las relaciones de poder en la hacienda de Tena. 1767-1805" (Tesis de pregrado, Universidad Nacional de Colombia, Bogotá, 2005). Agradezco a Jorge Gamboa por los comentarios sobre este texto.

${ }_{2}^{2}$ Como han demostrado varios teólogos que señalan el predominio del pensamiento platónico y neoplatónico en la teología medieval europea. Afirmación que confirmaría, para el caso de la América española, Anthony Pagden, La caída del hombre natural: el indio americano y los origenes de la etnología comparativa (Madrid: Alianza, 1988); JosephIgnasi Saranyana, Breve historia de la filosofia medieval (Pamplona: Universidad de Navarra, 2001); Felipe Castañeda, El indio entre el bárbaro y el cristiano. Ensayos sobre filosofia de la conquista en Las Casas. Sepúlveda y Acosta (Bogotá: AlfaOmega, Universidad de los Andes, 2002).

${ }^{3}$ David Davis, El problema de la esclavitud en la cultura occidental (Bogotá: Áncora, Universidad de los Andes, 1996).

${ }_{5}^{4}$ Clifford Geertz, La interpretación de las culturas (Barcelona: Gedisa, 2000).

${ }^{5}$ Como la denominó Moses Finley, la esclavitud en Grecia y Roma antiguas en el libro Esclavitud antigua e ideología moderna (Madrid: Crítica, 1982).
} 
Alonso de Sandoval, publicado en $1627^{6}$. En un período de tiempo en que la negación de la historia de la población de África subsahariana era una de las estrategias discursivas de exclusión y dominio ${ }^{7}$, el interés del padre Sandoval por los pueblos etíopes hace del Tractatus un caso único en su género, pese a la innegable semejanza con el De procuranda Indorum salute, del padre Joseph de Acosta.

La riqueza de la información consignada por Sandoval -que podríamos denominar etnográfica - no solo estuvo correlacionada con las estrategias de conversión y sujeción usadas por la comunidad jesuita. Las costumbres, las lenguas y las prácticas religiosas de los etíopes son indicativos de una construcción cristiana del ser humano en la que se pueden observar elementos de la escolática tomista y del platonismo agustiniano, y que convierten el Tractatus en un texto vital para observar bajo qué preceptos se legitimó la trata negrera.

Para Sandoval, los etíopes eran descendientes de Cam, hijo maldito de Noé, cuyo pecado originó el carácter inferior inscrito en los cuerpos y las almas de los pueblos de color oscuro. Su idea sobre la legitimidad de la esclavitud se fundó, entonces, en dos nociones de la moral dual cristiana. La primera, en la consideración de la esclavitud como una forma de sacrificio corporal que permitiría salvar el alma (dualidad alma-cuerpo). La segunda, en la idea de que la sumisión de los esclavos era una condición necesaria para mantener el orden social, puesto que estaba en concordancia con la jeraquización natural de los individuos dentro de la Ecclesia, consagrada por designio divino (dualidad comunidad-individuo).

Para ilustrar mejor las diferencias mencionadas de soslayo entre el pensamiento de Sandoval y Aristóteles, tomé como referente la construcción de cuerpo, siguiendo las ideas propuestas por David Le Bretón ${ }^{8}$. Como ha señalado el autor francés, el

\footnotetext{
${ }^{6}$ De los artículos y libros que han versado sobre la obra de Sandoval podemos mencionar, entre otros, Jaime Borja, "Lo culto y lo salvaje: del fantasma del negro pagano al negro adoctrinado. Actitudes y tendencias de dos desterritorializaciones S. XVII", mecanografiado (Bogotá, 1991); Rostros y rastros del demonio en la Nueva Granada: indios, negros, judios y otras huestes de Satanás (Bogotá: Ariel, 1998); Adriana Maya, "Memorias en conflicto y paz en Colombia: la discriminación hacia lo(s) negro(s)", en Culturas y transformaciones sociales en tiempo de la globalización (Bogotá: ICANH, 2003); Brujería y reconstrucción de identidades entre los africanos y sus descendientes en la Nueva Granada, siglo XVII (Bogotá: Ministerio de Cultura, 2005); Jean Pierre Tardieu, "Du bonne usage de la monstruosite: la vision de l'Áfrique chez Alonso de Sandoval, (1627)", en Bulletin Hispanique (Bordeaux, Francia), 86 (1984): 164-178; Margaret Olsen, Slavery and Salvation in Colonial Cartagena de Indias (Gainsville: University Press of Florida, 2004).

${ }^{7}$ Maya, "Memorias en conflicto".

${ }^{8}$ David Le Bretón, Sociología del cuerpo (Buenos Aires: Nueva Visión, 2002).
} 
cuerpo no debe ser considerado solo como una mera entidad biológica, sino como una construcción social y cultural, estrechamente ligada a la de ser humano. Marco analítico pertinente, si se tiene en cuenta, primero, que desde la Antigüedad la legitimación de la esclavitud se basó en la idea de una inferioridad natural inscrita en los cuerpos de los esclavos ${ }^{9}$. En segunda medida, una aproximación corporal ayuda a dilucidar las redes de significación que dieron sentido a la esclavitud y permite resaltar las diferencias, semejanzas, correlaciones, superposiciones y contradicciones en la obra de los dos autores, objeto de este estudio, sin obviar el contexto de las culturas en que vivieron.

Antes de desarrollar el análisis, es de mencionar que para facilitar la lectura comparativa entre Aristóteles y Sandoval decidí organizar los correspondientes apartados según los mismos parámetros: la concepción de ser humano, las bases sobre las cuales sustentaron la inferioridad natural de los esclavos -es decir, la legitimidad de su trata- $\mathrm{y}$, por último, la relación ideal amo-esclavo y su pertinencia para el mantenimiento del orden social.

\section{Aristóteles y la esclavitud en Atenas (siglo IV a.C)}

En Atenas la noción de esclavo estuvo ineludiblemente ligada a la de bárbaro, término usado para designar a las poblaciones no griegas. La reformas emprendidas por Clístenes (592 a.C), Solón (510 a.C) y Pisistrato (560-527 a.C), no solo volvieron más rígidas las condiciones de aquellos que podían considerarse ciudadanos, también promovieron la adquisición de esclavos extranjeros -debido a la prohibición de la esclavitud por deudas- y ahondaron la diferencia entre ciudadanos y bárbaros. Dualidad que, a largo plazo, se tradujo en la equivalencia entre bárbaro y esclavo ${ }^{10}$.

Sin embargo, la sinonimia entre estos dos términos tuvo otros orígenes y connotaciones más complejas, que trascienden el aspecto jurídico y económico. Como veremos más adelante, la construcción de la noción de inferioridad fue, en el pensamiento aristotélico, contraria a la de libertad, considerada como un ejercicio de la racionalidad, de lo político y lo público. De esta manera, mientras la democracia y la oligarquía, propias de las polis griegas, reflejaban el carácter libre de sus ciudadanos, la tiranía y el despotismo en los pueblos bárbaros simbolizaban un menor raciocinio y una tendencia natural hacia la servidumbre.

\footnotetext{
${ }^{9}$ Davis, El problema de la esclavitud.

${ }^{10}$ Cristóbal González, "Los metecos atenienses: un punto de vista sobre las clases sociales en la antigua Grecia”, en Clases y lucha de clases en la antigua Grecia, Claude Mosse, Pierre Vidal y otros (Madrid: Akal, 1977); Moses Finley, La Grecia antigua: economía y sociedad (1953; reimpresión, Barcelona: Crítica, 1984), 367.
} 


\section{La construcción del ser}

En la antigua Grecia, el cuerpo de los seres humanos era concebido como una materia inerte, cuya composición no se diferenciaba de la de formas como piedras, plantas, animales, en tanto era una combinación de los cuatro compuestos del universo: agua, tierra, aire, fuego. En esta perspectiva, era el alma la que dotaba de vida a los seres, el hálito que movía los cuerpos.

Varios filósofos de la Antigüedad estudiaron la relación alma-cuerpo, entre ellos, Aristóteles, uno de los pensadores más originales en esta disquisición. Mientras que Sócrates, Platón y otros pensadores de la Academia profundizaron en las cuestiones morales del alma, Aristóteles se interesó en señalar la distinción entre la materia inerte y los seres vivos; postura que se ha denominado como psicobiologicista ${ }^{11}$.

Para Aristóteles, el alma es la forma del cuerpo ${ }^{12}$, por lo tanto, el alma humana no puede habitar otro tipo de materia. De igual manera, en la medida en que el alma define el cuerpo, se convierte en principio y fin del ser, es decir, es entelequia de los seres vivos. Aspecto en el que difiere de Platón, para quien el cuerpo era un accidente, un vestido que ocupa temporalmente el alma y que puede cambiar en la reencarnación, como se puede observar en el Fedón ${ }^{13}$, cuando Sócrates señala que, en la muerte, el cuerpo humano podía transmutarse al de un animal o una planta.

Por lo anterior, la diferencia entre los seres vivos se debe a la posesión de alguno de los cuatro tipos o facultades del alma, denominadas: nutritiva, sensitiva, motriz o de movimiento e intelectiva. Las plantas poseen solo el primer tipo de ánima, los animales los siguientes dos, y sólo el hombre puede poseer el cuarto tipo, el ánima intelectiva, por medio de la cual puede pensar y razonar. Estas facultades se superponen, es decir, la posesión de un tipo de alma presupone los tipos inferiores; por ejemplo, el hombre, en tanto tiene alma intelectiva, posee las capacidades nutritiva, sensitiva y motriz.

Si bien los seres vivos tienen distintos tipos de alma, Aristóteles distingue entre la potencia y las acciones. El alma no es la que siente o la que se mueve, es la que le da al ser la potencia, la capacidad para llevar a cabo tal acción: "El alma [no es] quien compadece, aprende o discurre, sino [que es] el hombre en virtud del alma. Esto no significa, en cualquier caso, que el movimiento se dé en ella, sino que unas

\footnotetext{
${ }^{11}$ Como afirma Juan Cruz en "Introducción", en Cuestiones disputadas: sobre el alma, Tomás de Aquino (Pamplona: Universidad de Navarra, 1999), 281.

${ }^{12}$ Aristóteles, Acerca del alma (Madrid: Gredos, 1978), 262.

${ }^{13}$ Platón, Diálogos (Bogotá: Talleres de Gráficas Modernas, 1994), 3:371.
} 
veces termina en ella y otras se origina en ella"14. Entre tanto, el cuerpo es el accionar, el que permite llevar a cabo los movimientos, la alimentación, la reproducción y las otras facultades de los seres.

En el caso de los seres humanos, aunque Aristóteles señala que los cambios en la materia -como la vejez- corrompen los órganos y entorpecen las facultades, no alteran el intelecto, el cual es de carácter divino ${ }^{15}$. En otras palabras, en el hombre el accionar del alma intelectiva no es corporal; se produce por medio del pensamiento y la razón, que se nutren y perfeccionan con la discusión, con la capacidad de manifestar los pensamientos por medio de la palabra. Es en este aspecto que el Estagirita señala la correlación y la incidencia que tiene el accionar del intelecto con el ejercicio político de los ciudadanos.

En el libro La política, Aristóteles afirma que la naturaleza brindó la capacidad del habla a los hombres para que pudieran expresar lo bueno y lo malo. El habla es así el instrumento por excelencia de la justicia, virtud que posibilita la asociación de los seres humanos en comunidad; siendo la democracia -principalmente- y la aristocracia las formas políticas donde es más efectiva la administración de la equidad y la convivencia.

Como gobierno del pueblo (demos: pueblo, cracia: gobierno), la democracia estaba fundamentada en varios principios: igualdad de los ciudadanos, similares posibilidades de participación política y discusión oral y abierta para la toma de decisiones. La democracia es justa en dos sentidos: por una parte, permite la participación igualitaria de los individuos y, por otra, las decisiones políticas, al ser discutidas de manera abierta, oral, entre todos los ciudadanos, no están ligadas a los caprichos de una pequeña población -como en el despotismo o en la tiranía.

En tanto tenían participación política, mediante la discusión en espacios como el ágora, los ciudadanos podían accionar y aumentar su capacidad intelectiva. A su vez, solo eran ciudadanos aquellos que habían aumentado su intelecto por medio de la retórica, la oratoria y la memoria, aprendidas en espacios como el gimnasio ${ }^{16}$. Podemos afirmar, en resumen, que únicamente aquellas personas que tenían capacidad para accionar el alma intelectiva podían ser ciudadanos y, viceversa, solo la participación política permitía poner en acción la razón y el pensamiento.

\footnotetext{
${ }^{14}$ Aristóteles, Acerca del alma, 155.

${ }^{15}$ Ibídem.

16 Richard Sennet, Carne y piedra: el cuerpo y la ciudad en la cultura occidental (Barcelona: Alianza, 1994), 454.
} 
Como veremos a continuación, esta correlación entre política y ejercicio intelectivo sustentó la noción del bárbaro como ser inferior, irracional y, por ende, esclavo por naturaleza.

\section{Los esclavos en Aristóteles}

\section{El ser de los esclavos}

En uno de los apartes de La política, Aristóteles afirma: "Porque decimos que nada llega a su pleno desarrollo, por ejemplo, un hombre, un caballo, una familia, si no es siguiendo su proceso natural. Ahora bien, la meta y fin de una cosa es [lo] mejor, y precisamente autarquía es ambas cosas, el fin y lo mejor"17.

Como observamos en la cita, desde su origen los seres y los objetos están determinados por una acción divina o de la naturaleza, que en su pleno desarrollo los dota de unas condiciones y características particulares. Postura tautológica en la que se considera que los esclavos tienen tal condición en cuanto son esclavos.

Siendo consecuentes con la noción de entelequia y unidad del ser, se puede considerar que el alma y el cuerpo de los esclavos poseían características inferiores, lo que Aristóteles parece remarcar, al señalar que la naturaleza tiende a hacer los cuerpos de los esclavos más fuertes que en los libres ${ }^{18}$. Sin embargo, la capacidad física no es innata a todos los esclavos, así como: "muchas veces ocurre lo contrario: que los esclavos tienen, los unos, cuerpos de personas libres, y los otros, almas" $" 19$.

El sino de la esclavitud, por tanto, no se refiere a una marca física - puesto que algunos libres tienen los mismos rasgos corporales-, se remite más al plano del alma intelectiva y al ejercicio político ${ }^{20}$, ya que mientras algunos pueden ejercer la razón y ser ciudadanos, otros no, por lo que su mayor provecho es el uso del cuerpo para el trabajo ${ }^{21}$.

\footnotetext{
${ }^{17}$ Aristóteles, Política (Bogotá: Imprenta Instituto Caro y Cuervo, 1989), libro 1, capítulo 2. Las citas extraídas del libro Política se harán por el libro y el número de capítulo, teniendo en cuenta que existen múltiples versiones del texto que pueden ser preferidas por el lector.

${ }^{18}$ Ibídem, lib. 1, cap. 4.

${ }^{19}$ Ibídem, cap. 5 .

${ }^{20}$ Carlos García y Aurelio Pérez, "Introducción”, en Aristóteles, Política, señalan esta profunda relación que establece Aristóteles entre el homo politicus y el homo con logos.

${ }^{21}$ Aristóteles, Política, lib. 1, cap. 5.
} 
Recapitulemos. Anteriormente habíamos señalado que los seres humanos poseen alma intelectiva. El alma intelectiva es forma y entelequia del cuerpo, por lo que se puede considerar que todos los seres humanos son iguales o semejantes. No obstante -al señalar Aristóteles que unos humanos están más capacitados para el ejercicio político que otros-, el sino de la esclavitud hace referencia más a la puesta en acción del alma que a un tipo particular de la misma.

Pero surge una contradicción. Si la diferencia radica en la acción del alma y -como ya señalamos- esta actividad está relacionada con la retórica, la oratoria y otras artes que pueden ser aprendidas por los esclavos, entonces ¿dónde radica la distinción natural entre esclavos y hombres libres?

La esclavitud está relacionada con los pueblos bárbaros ya que, "Hay pueblos que, arrastrados por una tendencia natural a la servidumbre, inclinación mucho más pronunciada entre los bárbaros que entre los griegos (...), soportan el yugo del despotismo sin pena y sin murmurar",22.

Para el Estagirita, la voluntad es el deseo y el reconocimiento de la libertad. Puesto que la capacidad desiderativa es una de las características del alma sensitiva, la libertad es propia de todos los seres vivos. No obstante, a diferencia de los animales salvajes, en los seres humanos la libertad está ligada al logos y al ejercicio político. Ahora bien, puesto que la democracia es el gobierno de los individuos que se reconocen a sí mismos como libres e iguales, los seres humanos con voluntad tienden a asociarse democráticamente.

Los bárbaros, al tener gobiernos de tiranos o déspotas, no solo niegan su capacidad racional, además reflejan la inexistencia de voluntad, al dejar a un pequeño grupo las decisiones políticas. El gobierno tiránico o despótico no es considerado en sí un ejercicio de libre albedrío, al contrario, es un reflejo de carencia total de voluntad de estos seres humanos.

La relación que se estableció entre bárbaro, inferior y esclavo no fue propia de Aristóteles. Como señala Sennet ${ }^{23}$, la desnudez de los cuerpos cumplió una función importante en el ejercicio de la ciudadanía ateniense, ya que era indicativa del calor corporal, signo de la capacidad de racionamiento y de la participación democrática. Los bárbaros, en cuanto vagaban cubiertos por los bosques, reflejaban la frialdad de sus cuerpos y, por ende, su incapacidad racional.

No obstante, la relación que Aristóteles establece entre bárbaro y esclavo no es absoluta, como se evidencia en su inconformidad con el uso de mecanismos

${ }^{22}$ Ibídem, lib. 3, cap. 9.

${ }^{23}$ Sennet, Carne y piedra, 454. 
violentos para reducir a los extranjeros. Según el autor, no todos los bárbaros son iguales, pues distingue entre el pueblo llano, que ha sido siempre dominado, y la nobleza dominante. Los primeros serían esclavos por naturaleza, los segundos, en cambio, al mantener su libertad en el ejercicio político, no podrían ser considerados como tales. Distinción que la guerra no permite mantener.

Contrario a lo que se podría suponer, esta crítica a la guerra no se fundaba en una posición contra la práctica esclavista o un pensamiento movido por la compasión, sino en la importancia de la justicia para el equilibrio de la comunidad ciudadana de las polis griegas: "La justicia es una necesidad social, porque el derecho es la regla de la vida para la asociación política, la decisión de lo justo que constituye el derecho" ${ }^{24}$.

\section{El esclavo como instrumento}

Como observamos, en el esclavo la inactividad del alma intelectiva lo aproxima al cuerpo, a la materia. Aristóteles usa los conceptos de instrumento y propiedad para resaltar esta condición especial de humanidad.

Propiedad es una palabra que es preciso entender como se entiende la palabra parte: la parte no solo es parte de un todo, sino que pertenece de una manera absoluta a una cosa distinta de ella misma. (...) El que por ley natural no se pertenece a sí mismo, sino que, no obstante ser hombre, pertenece a otro, es naturalmente esclavo (...) se convierte en una propiedad, y como propiedad es un instrumento de uso y completamente individual ${ }^{25}$.

Según Aristóteles, la naturaleza busca la perfección, y la autosuficiencia es la perfección y su condición óptima ${ }^{26}$. El esclavo, al no poseer logos ni voluntad, no es un ser completo -como se ejemplifica en el uso de la palabra parte-, así que depende para su subsistencia del amo, de la razón. Como el cuerpo no puede estar separado del alma, de la misma manera el esclavo no puede estarlo del amo. El esclavo era una extensión del cuerpo de los amos -como señaló Davis ${ }^{27}$.

El pensador griego define la propiedad como un agrupado de instrumentos necesarios para la vida, que difieren según su finalidad. Distingue entre la propiedad que no tiene otro fin que su uso, como la cama o los zapatos, a lo que denomina posesiones, y los instrumentos prácticos, que son los que permiten producir otros bienes y cuya función va más allá del simple uso, lo que sucede, por ejemplo, con los molinos.

\footnotetext{
${ }^{24}$ Aristóteles, Política, libro 1, capítulo 2

${ }^{25}$ Ibídem, cap. 4.

${ }^{26}$ Ibídem.

${ }^{27}$ Davis, El problema de la esclavitud.
} 
Siguiendo esta distinción, el esclavo es un tipo de propiedad "subordinado para las cosas prácticas" 28 ; como operario, es el primer instrumento de todos y está destinado a la acción: "Pues si cada uno de los instrumentos pudiera realizar por sí mismo su trabajo, cuando recibiera órdenes (...) para nada necesitarían ni los maestros de obras de sirvientes ni los amos de esclavos" ${ }^{\text {"29 }}$.

Gracias a esta exaltación de su función corporal, el esclavo es reducido a su capacidad para el movimiento, es decir, se aproxima a los animales que se caracterizan por tener alma motora, principalmente a los proveedores de fuerza corporal - como los animales de carga y tiro- como resalta Aristóteles al citar a Hesiodo, "Ante todo, casa, mujer y buey de labranza'. Porque el buey hace las veces de esclavo para los pobres" ${ }^{\prime \prime}$.

Como fuerza motora, los esclavos no son considerados esenciales -pues, según vemos, el buey de labranza puede suplirlos-, de allí la afirmación de que los amos pueden vivir sin esclavos, pero no los esclavos sin amo. Sin embargo, el autor señala que muchos instrumentos necesitan de los esclavos para su funcionamiento. Asimismo, los esclavos eran indispensables en la ciudad, si se tiene en cuenta que el mantenimiento de esta forma de comunidad estaba correlacionado con la consagración del tiempo de los ciudadanos a la perfección racional, al desprendimiento de las preocupaciones terrenas ${ }^{31}$. Como señaló el Estagirita, los humanos que dependían de su trabajo para su existencia o usaban su tiempo para satisfacer las necesidades corporales -como el afán de lucro-, convertían su alma en esclava del cuerpo. En este aspecto, el trabajo de los esclavos era fundamental para asegurar el ocio necesario para el crecimiento de la racionalidad que sustentaba la vida citadina ${ }^{32}$.

Como veremos a continuación, la relación esclavo-amo, que se evidencia cada vez más como una entidad, como unidad inseparable, tuvo especial importancia en la vida familiar ateniense.

\section{El esclavo en la familia}

\footnotetext{
${ }^{28}$ Aristóteles, Política, lib. 1, cap. 4.

${ }^{29}$ Ibídem.

${ }^{30}$ Ibídem, cap. 2.

${ }^{31}$ García, "Introducción".

${ }^{32}$ González, "Los metecos".
} 
Según Aristóteles, en la jerarquización del cosmos hay tres formas de asociación de los seres humanos para su conservación ${ }^{33}$, denominadas comunidades: la familia, el pueblo y la ciudad. Mientras que la ciudad era la forma más perfecta y racional de asociación, puesto que se basaba en la libertad y tenía como fin la felicidad y la iluminación intelectiva de sus integrantes, la familia era la forma más primitiva de agrupación, con una rígida distinción jerárquica, basada en las características de sus miembros, que les asignaba ciertas funciones y deberes (diáthesis) ${ }^{34}$.

Compuesta por el padre, los hijos, la esposa y los esclavos, en la familia griega solo el primero, como ser superior y completo, tenía la categoría de ciudadano, y podía relacionarse públicamente en la ciudad con sus iguales. A diferencia de lo anterior, los hijos y, sobre todo, las mujeres y los esclavos, considerados como seres fríos y con menor capacidad racional ${ }^{35}$, estaban relegados al interior del hogar, a la esfera privada del oikos.

Debido a que la construcción del ciudadano ameritaba el ocio y el desprendimiento corporal, era la esfera privada de la familia la que complementaba al ser, en tanto aseguraba la manutención y las otras necesidades materiales. La distinción de funciones señalaba que era el esclavo, y su trabajo, el que debía asegurar la scholé de los amos. Es decir, la complementariedad amo-esclavo, cuerpo-alma, tomaba forma y sentido dentro del hogar ateniense -como lo demuestra el término usado para esclavo oikeus - , y generaba formas particulares de sujeción en las unidades domésticas.

Aunque los esclavos pertenecían a la comunidad familiar, sus libertades y derechos diferían de los de los demás miembros. El esclavo no podía tener familia, propiedad o religión; su familia era la del amo; su religión, la de la familia ateniense que lo poseía, y, como parte del amo, no tenía propiedades. Asimismo, la esclavitud no implicaba vínculos afectivos; puesto que eran instrumentos prácticos, los esclavos hacían parte de la administración económica del hogar, de la denominada crematística.

Ahora bien, el esclavo debía reconocer su inferioridad y su supuesta dependencia del amo, aceptando la estructura y división de funciones en las familias. Es decir, debía respetar el orden natural del mundo, de la naturaleza que lo había signado como esclavo, buscando la asimilación, la armonización de sus fines con los del amo.

\footnotetext{
${ }^{33}$ Se debe entender conservación como la reproducción y las condiciones esenciales para la supervivencia de los miembros.

${ }^{34}$ Pagden, La caída del hombre.

${ }^{35}$ Sennet, Carne y piedra, 27.
} 
Este acuerdo y concientización del esclavo estaban estrechamente relacionados con los ritos que aseguraban su pertenencia al oikos. Como señala Fustel de Coulanges $^{36}$, los esclavos, luego de ser adquiridos, ingresaban a la religión doméstica. Como su nombre lo indica, la religión doméstica se practicaba en torno al altar familiar, centro medular de las casas atenienses, y su práctica ritual estaba vedada a cualquier extraño. Al aceptar la religión, el esclavo aseguraba su admisión como un miembro más de la comunidad, con el derecho de celebrar las festividades religiosas y la oración y con los deberes propios de su condición. Pertenencia que se extendía más allá de la manumisión, puesto que los libertos y sus hijos seguían perteneciendo al núcleo familiar primigenio, y estaban obligados a pedir permiso a su antiguo amo para contraer nupcias.

Igualdad en el ámbito ritual, que sustentaba una relación comunitaria legitimadora de la esclavitud, y desigualdad en el plano productivo, basada en una rígida distinción jerárquica en el oikos, que permitía el mantenimiento del ciudadano, eje de la comunidad citadina. En esta dualidad, que podemos considerar característica de la Atenas clásica, los esclavos, pese a que eran considerados como una propiedad, no eran seres individualizados, entes independientes del amo y de la familia. Sus seres corporales y espirituales hacían parte de la entidad del amo, al que complementaban. De igual manera, eran un engranaje integral de la comunidad, bases sobre las que descansaba el orden familiar y el ámbito público de la ciudad. Unidad que, como veremos a continuación, se disolvió en el cristianismo gracias al poder pastoral y a otras prácticas del sí que escindieron al esclavo del amo.

\section{La maldición de Cam: la esclavitud en Alonso de Sandoval}

El hecho de que los etíopes fueran descendientes de Cam, el hijo de Noé, los hizo inferiores en cuerpo y alma. No obstante, para Sandoval, la esclavitud no era una condición sine qua non de estas poblaciones africanas; a diferencia de Aristóteles, la legitimidad de la reducción a esclavitud no se basaba en consideraciones ius naturalistas $^{37}$, sino en la concepción de dicha práctica como mecanismo para la conversión de estos pueblos al credo cristiano.

Ahora bien, pese a que en la descripción que hace Sandoval de África abundan los seres mitológicos y las figuras monstruosas, lo que podría ser interpretado como

\footnotetext{
${ }^{36}$ Numa Denis Fustel de Coulanges, La ciudad antigua: estudio sobre el culto, el derecho y las instituciones de Grecia y Roma, t. 1 (Bogotá: Panamericana, 1996).

37 Como observamos, la esclavitud para Aristóteles estaba fundada, primero, en una distinción natural entre seres y su necesidad para la reproducción de la comunidad.
} 
signo de la proximidad de esta tierra con el infierno ${ }^{38}$, tampoco se puede señalar que para el jesuita la esclavitud fuera una estrategia por medio de la cual se buscara reducir a los agentes del demonio en la lucha escatológica cósmica.

Para Sandoval, los etíopes tenían alma espiritual y eran, por lo tanto, seres humanos, aunque de condición inferior. El recurso estilístico de su obra, por lo tanto, buscaba describir cómo era una tierra alejada de Dios, para persuadir a los amos y a los miembros de la sociedad colonial de que la evangelización de los etíopes era una tarea urgente, para mantener la armonía de la Comunidad de la Iglesia. La esclavitud entonces adquirió sentido dentro de una economía de la salvación y una estética del cosmos cristiano, donde la iluminación espiritual se asemejó en diversos aspectos a un viaje dantesco.

La esclavitud debemos entenderla como una prueba impuesta por Dios a los etíopes para limpiar el pecado de su ascendente Cam, en la que debían superar tres estadios ascendentes: un mundo inferior contenido en la imperfección del cuerpo y el alma; un estadio intermedio, en la que los etíopes debían convertirse al credo cristiano y, correlativamente, asumir la esclavitud como una forma sacrificial, en la que debían estar supeditados al amo, y, por último, el estadio de la salvación, donde hay una transformación espiritual y corporal, que los equipara a las poblaciones europeas y les abona el terreno para la entrada al paraíso.

Conservando este orden ascendente, primero se observará cuáles eran las características inferiores de los etíopes; en un segundo apartado se ahondará en la esclavitud y su legitimidad; en el tercero se observará la relación amo-esclavo propuesta en Un tratado sobre la esclavitud, resaltando la noción de cuerpo como inferior y antagónico al desarrollo espiritual humano, propia de la moral cristiana que se buscó imponer.

\section{El cuerpo negro, la mente oscura}

\section{El cuerpo}

San Agustín, san Isidoro de Sevilla y otros pensadores consideraban que la humanidad no se podía desligar de lo anatómico ${ }^{39}$. Puesto que todos los seres humanos fueron hechos a imagen y semejanza de Dios, quien, desde la concepción

\footnotetext{
${ }^{38}$ Enriqueta Vila Vilar, "Introducción", en Un tratado sobre la esclavitud, Alonso de Sandoval (Madrid: Alianza, 1987); Borja, Rostros y rastros; Maya, "Memorias en conflicto".

${ }^{39}$ Maya, "Memorias en conflicto".
} 
eurocéntrica de la época, se asemejaba a las poblaciones blancas europeas ${ }^{40}$, el color oscuro de los etíopes generaba dudas sobre su condición humana.

Para Sandoval, los etíopes son una desviación del ser humano original, una creación divina frustrada. Para aclarar el origen de esta falla, el jesuita debatió varias hipótesis de los autores clásicos, usando su conocimiento empírico y las revelaciones bíblicas para argumentar alternadamente a favor y en contra, hasta hallar la verdad total -parafraseando al Aquinate.

Primero, retoma a Aristóteles, para quien el origen de la diferencia que se observa entre los padres y su descendencia era producto de una gran capacidad imaginativa de algunos seres: "Persina Reyna de Etiopía (...) concibió una hija muy blanca, porque al tiempo de la concepción ahincó los ojos y la imaginación atentamente en la imagen de la hermosa Andrómeda"41.

Donde la imaginación es una de las cualidades del alma intelectiva, "la raciona ratiosina, discurre e imagina" 42 . Aunque, la concepción aristotélica del alma como forma y entelequia del cuerpo explica transformaciones como esta en la materia, para Sandoval el alma intelectual no explica del todo el origen del color oscuro: "[debido a la imaginación, vemos] de padres blancos, hijos morenos y aun muy negros: y de padres negros, hijos muy blancos, rubios, zarcos y colorados" ${ }^{, 43}$.

En los etíopes, el color oscuro es el original, característica primigenia y esencial de los negros. La desviación en la creación se debe remontar más atrás en el tiempo, pues no es una característica de unas cuantas generaciones. Sandoval explora así otras hipótesis. Una de ellas señalaba que el extremo calor de las zonas tórridas africanas generó las características particulares de la raza etíope, como es el color negro, el cabello rizado y los dientes blancos ${ }^{44}$. Pero el padre Sandoval rechaza esta explicación ambientalista señalando casos de blancos, habitantes de África, que conservaban su color natural, pese al calor del entorno, así como de etíopes que, no obstante vivir en Europa, mantenían la tez oscura.

\footnotetext{
40 Álvaro Félix Bolaños, Barbarie y canibalismo en la retórica colonial: los indios pijaos de fray Pedro Simón (Bogotá: Cerec, 1994), 243.

41 Alonso de Sandoval, Un tratado sobre la esclavitud (1627; reimpresión, Madrid: Alianza, 1987), 70.

42 Ibídem, 73.

43 Ibídem, 69.

${ }^{44}$ Determinismo que surgió desde la Antigüedad, cuando se pensaba que el calor de las zonas cercanas al Ecuador era un impedimento para el surgimiento de vida, y sí ella existía, los seres debían ser incompletos o de características monstruosas, como señaló Edmundo O'Gormann, La invención de América: investigación acerca de la estructura histórica del Nuevo Mundo y del sentido de su devenir (México: Secretaría de Educación Pública, 1992), 193.
} 
Seguidamente, el jesuita, retomando a Aristóteles, señala que el calor sí genera cambios en las formas de los seres vivos, pero no un calor externo, ambiental, sino el calor de la matriz de las madres ${ }^{45}$. Planteamiento que relaciona con el texto bíblico señalando que el color oscuro es: "una calidad innata e intrínseca, con que le crió Dios, que fue sumo calor, para que los hijos [de Cam] que engendrase, saliesen con ese tizne, y como marca de que descendían de un hombre que se había burlado de su padre" 46 .

Para el jesuita, los etíopes son descendientes de Cam. Afirmación basada en las similitudes lingüísticas entre los nombres, como comúnmente se conocía a África en la Biblia y el hijo de Noé, "la Sagrada Escritura, según el texto original hebreo, llama a la Abasia ${ }^{47}$, Chusis; y a los abasinos, sus naturales, chuseos tomando la derivación del nombre Chus, hijo de Cham, que la pobló" ${ }^{\text {"48 }}$.

A diferencia de Aristóteles, en este orden de ideas, el color oscuro debe ser considerado como una calidad intrínseca del cuerpo y no como una acción o un cambio originado por el alma intelectiva. Se empieza a evidenciar un distanciamiento del jesuita con los planteamientos del pensador griego que, como veremos luego, incidió en la construcción del etíope como ser con capacidad de entendimiento inferior.

El calor de la matriz de los etíopes puede ser asociado con el infierno, lugar donde el alma de los pecadores es castigada por medio de las llamas. Naturaleza infernal que parece apoyar Sandoval, cuando señala el mal olor: "Que así se trocó [la conversión de los etíopes] su mal olor en los almizcles del paraíso, (...) sabe dar [Dios] quilates a almas que le agradan, aunque hayan vivido en cuerpos que eran el ultraje y desecho del mundo"49.

Según Borja ${ }^{50}$, el olor de los negros se asemejaba al de los excrementos. Materia que en Occidente es sinónimo de impureza y que, en el imaginario de la Europa medieval, era asociado a lo demoníaco, puesto que proviene de la naturaleza

\footnotetext{
${ }^{45} \mathrm{El}$ ejemplo clásico usado por Aristóteles, y citado por Sandoval, Un tratado, 107, es el de los cuervos y los cisnes, animales que, no obstante vivir en similares condiciones ambientales, tienen un pelaje de color distinto.

${ }^{46}$ Sandoval, Un tratado, 107.

${ }^{47}$ Los nombres Abisinia o Abasia fueron usados desde la Antigüedad en el continente europeo como sinónimos de Etiopía o de África.

${ }^{48}$ Sandoval, Un tratado, 69.

${ }^{49}$ Ibídem, 293.

${ }^{50}$ Borja, Rostros y rastros, 390.
} 
inferior y baja de los cuerpos humanos ${ }^{51}$. Es decir, el mal olor era un signo que denotaba la procedencia infernal de los africanos.

Podemos señalar, entonces, que el cuerpo de los etíopes era inferior en varios sentidos. Primero, en tanto se alejan de la creación divina, de los rasgos físicos más perfectos de los blancos. Segundo, por la procedencia infernal de los etíopes. Tercero, de una manera real, por su procedencia geográfica. Veamos mejor este punto.

Según Bajtin ${ }^{52}$, en el pensamiento medieval y renacentista, el cosmos estaba jerarquizado en tres partes: el mundo inferior o el infierno, el mundo medio o la tierra donde viven los seres vivos, y el mundo superior o el cielo. Construcción que no solo es simbólica o relativa, sino que tuvo un sentido topográfico en el realismo grotesco de la cultura popular medieval; donde las cuevas, los agujeros de la tierra eran entradas al mundo subterráneo, a la posesión de Satán. Cuando se afirma, entonces, que los etíopes tienen una procedencia infernal, se debe entender que se está haciendo referencia a un mundo físico, a África, donde los seres monstruosos y las maravillas narradas por los viajeros y los autores antiguos eran signos de la presencia del mal y de la entrada al infierno -como ha señalado Borja ${ }^{53}$. . Los etíopes, por lo tanto, son inferiores de una manera real; provienen de abajo, de las cuevas, de los excrementos, del submundo.

\section{El entendimiento}

La inferioridad corporal de los etíopes embota la capacidad de entendimiento, la cual es, a su vez, inferior a la de los blancos: "Que parece que Dios, hablando a su estilo, había quitado la mitad del entendimiento a los esclavos (...) no porque se haya de creer que tienen menos perfectas almas que los muy libres, sino porque la misma vil condición del cuerpo embaraza el entender del alma" ${ }^{, 54}$.

Antes de analizar esta cita, quiero hacer una aclaración a la misma. Como podemos observar, Sandoval inscribe en los esclavos esta menor capacidad intelectiva y no en la generalidad de los etíopes; empero, a lo largo de su escrito, no indica la distinción natural entre estos, así que asumo que la apreciación cobija la totalidad de la población de color oscuro.

\footnotetext{
${ }^{51}$ Mijail Bajtin. La cultura popular en la Edad Media y en el Renacimiento: el contexto de François Rabelais (Madrid: Alianza, 1990), 430.

${ }^{52}$ Ibídem.

${ }^{53}$ Borja, Rostros y rastros.

${ }^{54}$ Sandoval, Un tratado, 234.
} 
Primero, observemos la concepción de entendimiento. Para Sandoval, está relacionado de tres formas con el conocimiento de Dios: 1) por una parte, el conocimiento de las verdades divinas "ilumina" el entendimiento: "un corazón que no se ilustra con rayos de fe, los ciega, tanto, que más parece alma de bruto la de un hombre, hecha a imagen y semejanza de Dios" ${ }^{\text {"55 }}$.

2) El entendimiento revela la existencia de Dios. Los etíopes tienen una menor capacidad de entendimiento debido a que: primero, desconocen la existencia de Dios y, segundo, porque, pese a la conversión de algunos pueblos etíopes al credo cristiano, estos se habían alejado de la verdadera doctrina, cayendo en vicios y errores: "predicada [la religión] antiguamente en todas aquellas partes, y después apagada y trucada por la industria del demonio y por los pecados de los hombres" $"$.

Al respecto, hay semejanzas entre la noción de entendimiento de Sandoval y el concepto tomista de razón. Para el teólogo medieval, las limitantes de la razón para explicar el mundo evidencian la existencia de un ente superior. Con esta perspectiva, el ejercicio de la razón no está desligado de la revelación divina, al contrario, permite comprobar la existencia de Dios, y, de manera recíproca, la ignorancia de un ente superior solo es reflejo de la incapacidad racional. Concepción que se evidencia en Sandoval cuando señala que las poblaciones africanas más civilizadas, con formas de gobierno mejor elaboradas y costumbres más perfectas, son las que tienen una religión más cercana al catolicismo.

3) La capacidad del entendimiento se entorpece por los deseos carnales. Esta premisa permite establecer tres relaciones con respecto al conocimiento de Dios: el interés por satisfacer al cuerpo impide que los hombres se dediquen al ejercicio racional; los deseos carnales, al ser considerados pecados, no solo alejan a los hombres del entendimiento, desvían el camino hacia la verdad; el ejercicio del entendimiento, considerado como opuesto a los deseos carnales, aleja el pecado y aproxima al ser humano a Dios.

Aunque Aristóteles usa también el concepto de entendimiento, las características y el significado dados por Sandoval a esta palabra hacen que se asemeje más al concepto de razón del autor griego. Para Aristóteles, el entendimiento es la primera forma de intelección de las percepciones físicas. La razón, en cambio, tanto en su aplicación aristotélica como en la tomista, es la correlación que se establece entre varias verdades del entendimiento. Es, por decirlo de algún modo, el siguiente paso en el saber.

\footnotetext{
${ }^{55}$ Ibídem, 233.

${ }^{56}$ Ibídem, 85.
} 
Sin embargo, hay una característica del entendimiento que la distingue del concepto aristotélico de razón. En el título anterior se observó que para Aristóteles la razón es considerada una acción del alma intelectiva. En cambio, para Sandoval el entendimiento $-o$ la falta de él- es una característica natural e intrínseca de los etíopes, "porque los negros comúnmente no tienen menos uso de razón que los españoles, que comúnmente llamamos tontos, o bobos" $"$ ".

Por lo tanto, podemos afirmar que, usando los términos de Aristóteles, para el jesuita el entendimiento no es una acción del alma intelectiva -como es el habla o la razón-, es una capacidad intrínseca dada a los seres humanos desde su nacimiento.

Otra de las diferencias entre Sandoval y Aristóteles está en la concepción de alma usada por el primero. Si somos consecuentes con el pensamiento aristotélico, podemos afirmar que la menor capacidad intelectiva se debe a un carácter inferior del alma de los etíopes. No obstante, Sandoval señala que "parece que Dios (...) había quitado la mitad del entendimiento a los esclavos (...) no porque se haya de creer que tienen menos perfectas almas" ${ }^{\$ 5}$.

Sandoval toma la noción de alma del cristianismo, según la cual Dios infunde esta sustancia a los humanos en el momento de nacer. El alma no es solo el halo de vida que mueve los cuerpos, es la parte divina e inmortal de los seres humanos. Alma espiritual, cristiana, que se diferencia del alma intelectiva -en la que se incluiría el entendimiento-. Para ilustrar mejor la disimilitud entre estos dos tipos de alma, cuyo primer exponente fue Aquino, es pertinente traer el modelo de Le Bretón ${ }^{59}$ de alma-cuerpo-pensamiento, donde el alma haría referencia al alma cristiana y el pensamiento, al alma intelectiva.

La construcción del esclavo como ser con un entendimiento inferior está correlacionada con un pensamiento evolutivo del ser humano de la Escuela de Salamanca y de autores como Acosta ${ }^{60}$, cuya influencia en el Tractatus es evidente $^{61}$. Puesto que, por ley natural ${ }^{62}$, todos los seres humanos tienden a conocer

\footnotetext{
${ }^{57}$ Ibídem, 480.

${ }^{58}$ Ibídem, 234.

${ }^{59}$ Le Bretón, Sociología, 65.

${ }^{60}$ Pagden, La caída del hombre.

61 Recordemos que una de las obras del padre jesuita José de Acosta se tituló De procuranda indorum salute y fue marco de referencia argumentativa y estilística del libro de Sandoval, como señaló Vila, "Introducción".

${ }^{62}$ Podemos entender en un doble sentido la noción del ley natural de Santo Tomás de Aquino y la aplicación que tuvo en la denominada Escuela de Salamanca, como señaló Pagden, La caída del hombre. En primera medida, son las leyes de Dios, tanto sociales como de tipo moral. En un segundo aspecto, en tanto que Dios creó a los hombres a su
} 
el bien y la verdad, la ignorancia de la existencia de un Dios por los etíopes es un reflejo de que ocupan un puesto inferior -debajo de los europeos- en la cadena evolutiva. Sin embargo, el hecho de que los etíopes tengan un alma cristiana explica y obliga su conversión, "Pues con poco que en ella se trabaje, bastará para la obligación que tienen de saber y entender las cosas del cielo" ${ }^{\text {"63 }}$.

Hay un punto que debemos reconsiderar. En la medida en que los etíopes tienen alma cristiana y han sido hechos por Dios, su naturaleza no es demoníaca, como habíamos sugerido anteriormente y podemos observar en una de las imágenes metafóricas usadas por Sandoval,

... y así como un carbón enciende al otro, así parece que la hermosura de su alma en cuanto pudo ser, se pegó y trasfundió en el carboncillo de su denegrido cuerpo; con cabeza tan resplandeciente y rostro hermoso, que todo lo sabe hacer la sabiduría de Dios, y todo lo puede su divina omnipotencia ${ }^{64}$.

Esta imagen del carbón que se enciende con la fe se asemeja a las usadas por el místico español Juan de la Cruz, sobre las que Von Baltasar afirma lo siguiente:

Y una vez que el amor purifica el alma, como el fuego que primero envuelve al leño, lo ennegrece y lo seca, y luego lo penetra por dentro con la llama, y lo torna semejante al fuego; es decir, cuando el alma alcanza la meta, la llama viva del amor [entiéndase, la revelación divina] la que arde es el cielo futuro ${ }^{65}$.

Donde el fuego no es el del infierno, sino el del espíritu dormido que se enciende con la conversión, por lo que la naturaleza de los etíopes es más de carácter purgatorial. El purgatorio, recordemos, dentro de la mitología católica es un espacio intermedio entre el infierno y el cielo, que alberga transitoriamente a las almas que pueden redimir sus pecados, siendo las llamas de la fe las que permiten transformar el espíritu de los condenados para poder entrar al reino de los cielos, "Que así se trocó [la conversión] su hambre en hartura, su tristeza, en gozo, su desnudez, en estola de inmortalidad, su mal olor, en los almizcles del paraíso,"66.

Es necesario anotar que el purgatorio, al que hacen referencia San Juan de la Cruz y Sandoval, difiere de la concepción actual. Este no es el círculo espiritual al que ingresan las almas luego de la muerte de los seres humanos, es un espacio topográfico, real: la tierra donde habitan los seres humanos.

imagen y semejanza, hay una comprensión natural de las cosas que debe encaminar a los seres hacia el bien moral, pese a que no conozcan a Dios o hayan sido cristianizados.

${ }^{63}$ Sandoval, Un tratado, 375-376.

${ }^{64}$ Ibídem, 228.

${ }^{65}$ Hans Von Balthasar, Gloria: una estética teológica (Madrid: Encuentro, 1986), 123.

${ }^{66}$ Sandoval, Un tratado, 293. Subrayado de la autora. 
Para su transformación espiritual, los etíopes deben superar dos tipos de pruebas impuestas por Dios, íntimamente ligadas dentro del orden social impuesto por designio divino: la conversión al credo cristiano y la actitud resignada frente a su condición de esclavos.

\section{La conversión de los etíopes}

\section{La esclavitud}

Argumentos contradictorios y poco claros expuestos en el Tractatus pueden conducirnos a dudar si para Sandoval la esclavitud era legítima -como señaló Vila Vilar $^{67}$-. Es indispensable, por consiguiente, revisar la línea argumentativa del jesuita para dilucidar si consideraba la esclavitud como una práctica permitida por Dios.

Como hemos observado, la esclavitud es una condición natural de los etíopes, si se tienen en cuenta dos de los racionamientos de Sandoval: estos pueblos descienden de Cam, por lo que han sido condenados a ser siervos de siervos; al haber creado Dios unos seres superiores y otros inferiores -me refiero a los etíopes-, estos últimos están destinados para servir a los primeros: "en la naturaleza [los seres humanos] son iguales, y en el nacimiento, semejantes; aunque, por discreta dispensación de Dios, unos son mayores y otros menores" ${ }^{\text {"68 }}$.

Sin embargo, Sandoval señala casos en que la esclavización ha sido lograda por medios ilegítimos, como es el de los reyes etíopes que usaron diversas artimañas como la promoción del adulterio- para esclavizar a sus súbditos ${ }^{69}$, lo que permite suponer que estos no estaban signados en su cuerpo o en su alma con la condición servil.

No obstante, la inexistencia de alguna característica física o moral particular que los identifique como esclavos, para Sandoval sí es una condición natural de los etíopes. Afirmación que se sustenta en una lógica axiomática y circular donde, en la medida en que la esclavitud existe, ha sido creada por Dios, como creador de todas las cosas y los seres. Y como Dios predestina desde su origen a los seres humanos, los esclavos lo son desde su nacimiento. Argumentación que se asemeja a la de Aristóteles, observada en el anterior título.

\footnotetext{
${ }^{67}$ Vila, "Introducción".

${ }^{68}$ Sandoval, Un tratado, 246.

${ }^{69}$ Ibídem, 148.
} 
Pero una duda parece surgir, si recordamos la afirmación de Sandoval de que Dios hizo en la creación a todos los seres humanos libres e iguales, "hasta que andando el tiempo y creciendo la malicia comenzaron unos a tiranizar la libertad de los otros" 70 . Es decir, al ser el pecado de la avaricia el móvil de la esclavización, esta ni ha sido creada por Dios ni es natural a unos seres humanos.

En este punto, cuando parece que Sandoval está a punto de señalar si existe una ley primaria o divina de la esclavitud, corta el discurso sin dejar claridad al respecto, para, a continuación, discutir la legitimidad de los mecanismos de reducción de los esclavos, citando una de las comunicaciones que mantuvo con el padre Brandón, rector de los jesuitas en Brasil, quien indicaba que, "Padres de nuestra religión eminentes en letras nunca tuvieron este trato por ilícito. (...) Y digo más, que cuanto alguien podía excusar de tener escrúpulos que llevan estos negros los llevan con buena fe, la puede vender" ${ }^{\text {, } 11}$.

Según la cita, el esclavo es concebido como una posesión, que puede ser adquirida o vendida a libre albedrío. La discusión se encamina a analizar sí la posesión de los etíopes y los mecanismos de reducción de estos pueblos se pueden considerar legítimos. Primero discute la veracidad de que los reyes etíopes sean propietarios de sus súbditos ${ }^{72}$. Sin embargo, como el padre había señalado, el uso de acciones ilegales para esclavizar a sus súbditos indicaría la falacia de esta afirmación.

Posteriormente, analiza la legitimidad de la propiedad de los esclavos en el caso de los tratantes blancos y relata la visita de dos comerciantes, que le expusieron su negocio señalando que las múltiples dificultades y peligros que corrían en la travesía transatlántica hacían que el cargamento de esclavos fuera legítimamente de su propiedad. A lo que el padre respondió que en estos casos el trabajo de los tratantes se asemejaba al de ladrones, a los cuales no se les reconoce como legítimas sus acciones, ya que fueron realizadas con mala fe.

En este aspecto, no hay claridad sobre las condiciones en que se puede considerar a los etíopes como esclavos. Tampoco se profundiza sobre sí las personas de tez oscura pueden ser consideradas como libres. Sandoval sólo se remite a reprochar la motivación fundada en los deseos pecaminosos de la avaricia y el enriquecimiento. Se inscribe así entre los críticos de la corriente de pensamiento renacentista que

\footnotetext{
${ }^{70}$ Ibídem, 149.

${ }^{71}$ Ibídem, 144

${ }^{72}$ Recordemos que esta práctica de dominio aparentemente se ejercía en África desde antes del establecimiento del comercio transoceánico.
} 
señala al hombre como centro del universo ${ }^{73}$, que se ejemplifica en la racionalidad economicista de los tratantes negreros.

Para el padre, la motivación de toda acción humana debe ser la salvación espiritual. Pensamiento que legitima la esclavitud, en cuanto se considera necesaria para la conversión de los pueblos africanos, como se puede observar en el siguiente extracto de la carta de Brandón: "Verdad es que tengo por cierto, que ningún negro dice ser bien cautivo (...) [pero] perderse tantas almas que de aquí salen, de los cuales muchos se salvan, por ir algunos mal cautivos, sin saber cuáles son, parece no ser tanto servicio de Dios por ser tan pocas" ${ }^{\prime 74}$.

Siguiendo la construcción jurídica de Santo Tomás, podemos señalar que la libertad de los etíopes es una ley secundaria, cuya violación es legítima si está en concordancia con la ley primaria o divina de la salvación de las almas. Salvación que, dentro de la estrategia confesional de Sandoval, estuvo compuesta por dos dominios: el bautismo y la educación ${ }^{75}$ en la relación amo-esclavo, puesto que los etíopes eran considerados, de manera similar a lo que Vitoria señaló de los indios ${ }^{76}$, como menores de edad que podían acceder a la razón y entendimiento de Dios solo a través de la figura paternal del amo.

\section{El cariz transformado}

Según Aubin ${ }^{77}$, el sacramento católico del bautismo se considera como un rito purificador por medio del cual los seres humanos limpian la mancha del pecado original de Adán y Eva, así como sus faltas pasadas. A su vez, simboliza la admisión del creyente en la comunidad de la Iglesia, su aceptación del orden social decretado por Dios y, por supuesto, el conocimiento del dogma cristiano. Característica última que fue motor de diversas disputas teológicas en el medioevo, pues era necesario aclarar cómo podía acceder el ser humano a la verdad divina, si el rito del bautismo debía ser antecedido por el conocimiento, o viceversa, o si podía acarrear la transformación mágica de las almas y los cuerpos de los ungidos.

\footnotetext{
${ }^{73}$ Alfred von Martin, Sociología del Renacimiento (México: Fondo de Cultura Económica, 1976); Tzvetan Todorov, La conquista de América: el problema del otro (México: Siglo XXI, 1999).

${ }^{74}$ Sandoval, Un tratado, 144.

${ }^{75}$ Educación que también debía ser entendida como la habituación, término aristotélico que hace énfasis en las leyes y las normas de comportamiento comunitario.

${ }^{76}$ Pagden, La caída del hombre, 141.

${ }^{77}$ Paul Aubin, El bautismo, ¿iniciativa de Dios o iniciativa del hombre? (Santander: Sal Térrea, 1987). También obtenido de la red mundial el 19 de octubre de 2005, 9:25 horas. http//www.corazones.org/finalidaddel bautismo.com.
} 
Una de las principales influencias para responder estas preguntas fue el platonismo ${ }^{78}$, cuyas nociones de esencia y forma fueron aportes principales en la teología medieval. Para san Agustín de Hipona, ilustre exponente de esta corriente, el bautismo cambiaba la esencia de las personas, aunque la forma permanecía impasible. En este caso, la revelación de Dios penetraba por el agua purificadora del rito convirtiendo las almas de los ungidos en cristianas conocedoras de la verdad. Desde esta perspectiva, contrario a lo que se puede suponer, no era necesaria la adultez o la madurez mental ni el conocimiento del dogma cristiano como prerrequisito para el bautismo.

Para el teólogo, el conocimiento de Dios no es externo al ser. Es una realidad inmaterial expresada en verdades innatas que Dios depositó en el alma. El santo propone un método cognitivo racional de tipo individualista y autorreflexivo, próximo al platonismo, donde los seres humanos buscan en su interior, por medio de la razón, las realidades de la fe. El bautismo era, en consecuencia, el acto por medio del cual Dios infundía la revelación en los espíritus, que podía ser alcanzada por medio de la meditación y el ensimismamiento de los creyentes.

Contraria a la construcción platónica de fe y razón, Aquino postuló -retomando a Aristóteles- un conocimiento de Dios más ligado a las realidades externas. Para santo Tomás, la razón es un proceso cognitivo que, por medio de nuestros sentidos, permite conocer la realidad, la naturaleza. Debido a que la naturaleza es una creación divina, la razón puede ser una vía para acceder a la verdad del verbo.

Para el Aquinate, otra forma de conocimiento es la revelación, que no puede ser cuestionada y en la que creemos por un acto de fe. Sin embargo, a diferencia de san Agustín, la verdad no solo habita en nuestro interior, está en los milagros y en otros actos divinos. La razón y la fe deberían, entonces, estar ligadas, trabajar juntas para acceder a la verdad total y alcanzar la salvación eterna.

En mi opinión, siguiendo la noción de fe y razón del doctor Angélico, hay una discrepancia con la concepción del bautismo como transformación de la esencia. Para santo Tomás, el bautismo por sí solo no logra la iluminación divina en los bautizados, más bien los prepara para su aceptación y asimilación de las verdades divinas. Abre la mente y el corazón de los seres humanos para recorrer el largo camino del acercamiento a Dios. Por lo mismo, el sacramento debe ser antecedido por un conocimiento adquirido, racional del dogma cristiano.

Sandoval se aproxima a esta noción tomista del bautismo. Aunque enfatiza en la importancia del agua bendita - por algo, una de sus quejas es que en los puertos negreros no todos los esclavos eran ungidos-, esta no es suficiente para la

${ }^{78}$ Ibídem. 
transformación del ser. A su vez, la revelación no es un acto total en el bautismo. Los esclavos deben conocer, acceder y razonar sobre la verdad divina, antes del bautismo, para que este tenga validez, por lo que consideraba necesario volver a bautizar a los etíopes. De esta manera, negó la magia del bautismo, la capacidad que tiene el agua bendita de transformar en esencia a los seres humanos en creyentes de Dios - la cual era una de las verdades fundamentales de este sacramento-. Postura que fue tildada como herética por el Tribunal de la Santa Inquisición y que acarreó varias investigaciones en su contra.

Como la razón es una vía para conocer a Dios y debería ejercitarse constantemente, por sus implicaciones morales y comportamentales en el individuo, Sandoval enfatiza en la importancia de la relación amo-esclavo, pues en ella se debe complementar la iluminación iniciática del sacramento.

\section{El padre y el hijo; el pastor y la oveja}

Para Sandoval, el fin misional de la conversión precisaba una actitud benevolente y compasiva de los amos hacia sus esclavos, y un comportamiento sumiso por parte de estos últimos. Esta visión paternalista fue promovida por san Pablo, para quien la humanidad de los esclavos obligaba a los amos a tener ciertas actitudes morales y cristianas con sus posesiones ${ }^{79}$. Para comprender mejor la lógica de esta relación ideal propuesta por Sandoval, se analizará la relación de los amos para con sus esclavos, para abordar, a continuación, la actitud de los segundos frente a los primeros.

\section{El amo}

Para Sandoval, la primera y principal función del amo debe ser la cristianización de sus esclavos debido a que tienen poco entendimiento: "crece la obligación en los señores de ser entendidos en lo que al esclavo importa, así para el bien del cuerpo, como principalmente del alma" ${ }^{\prime 0}$. La conversión debe ser asumida por los amos, en parte, como un acto de compasión, que sería recompensada por Dios en la eternidad, y a su vez como una misión impuesta por Dios a los europeos: "hasta que Dios les abrió camino [hacia África] para que levantasen el trofeo de la santa Cruz entre bárbaras e incógnitas naciones, y les quedase perpetua gloria de tan ilustre empresa" ${ }^{\prime \prime}$.

Los amos deben ser pastores de sus esclavos. Metáfora cristiana que evidencia una posición jerárquica en la labor de conversión, basada no solo en el conocimiento de

${ }^{79}$ Ernst Troeltsch, The Social Teaching of the Christian Churches, t. 1. (Kentucky: Westminster-John Knox Press, 1992).

${ }^{80}$ Sandoval, Un tratado, 234.

${ }^{81}$ Ibídem, 101. 
la doctrina y en la gradación natural, donde los blancos son superiores a los de tez oscura. Sandoval señala que esta relación compasiva debe incluir, además del alma, los cuerpos de los esclavos, por lo que los amos debían mantener una actitud compasiva con ellos.

Ha de tener el señor de esclavos entendimiento para mirar por sus cuerpos, halo de tener en los ojos, para mirar por sus necesidades, entendimiento en la lengua, para decirles buenas palabras: finalmente, entendimiento en las manos, para acudirles con lo necesario, para no obligarlos a que muchas veces lo busquen, con afrenta de sus amos, y ofensas de Dios ${ }^{82}$.

Cuatro son las razones para propugnar por este mejor trato físico. Primero, debido a que el cuerpo de los esclavos es humano y debe ser objeto de conmiseración por parte de sus amos. Segundo, pues los esclavos son considerados -literalmente- una inversión, esta, por lo tanto, deber resguardada. Tercero, porque el mejor trato físico - traducido en comida, vestido y vivienda- permite una mayor sumisión para la conversión. La última razón es digna de un análisis más detallado. Para Sandoval, los esclavos han sido dados por Dios a sus amos, "para que les enseñasen el camino del cielo, y allá les encaminasen con su buen ejemplo"83. El pensamiento del padre revela, entonces, algunas semejanzas con el aristotélico, ya que los esclavos son una posesión, orgánicamente dependiente del amo, quien es considerado como ente total y completo: "que si el esclavo tiene medio entendimiento, el amo ha de tener entendimiento y medio, el entero para sí; y el medio para que supla la otra mitad, que le falta a su esclavo" $"$.

Como el amo tiene una mayor capacidad de entendimiento, se establecen dos tipos de relaciones. Primero, en este ente amo-esclavo, el amo es la capacidad intelectiva y el esclavo un instrumento para la acción; el amo es el alma y el esclavo, el cuerpo. Segundo, el amo, al tener una mayor capacidad intelectiva, debe ser y comportarse como un padre con sus esclavos. Esta analogía es comprensible, teniendo en cuenta que para Santo Tomás de Aquino los padres son dueños de sus hijos y, a la vez, deben ser los guías que los encaminen por el bien ${ }^{85}$.

Pese a la similitud entre estas dos nociones de esclavitud, hay divergencias significativas. El esclavo en Atenas, desde el momento de su compra, pasaba a pertenecer a la religión doméstica, es decir, a la asociación comunitaria de la familia del amo. En cambio, la comunidad cristiana solo recibe entre sus miembros a aquellos individuos convertidos a la fe. Esta divergencia que impone la religión

\footnotetext{
${ }^{82}$ Ibídem, 235.

${ }^{83}$ Ibídem, 239.

${ }^{84}$ Ibídem, 234.

${ }^{85}$ Joaquín Zabalza Iriarte, Lectura sobre el derecho: Tomás de Aquino y Latinoamérica (Bogotá: Universidad Santo Tomás de Aquino, 1978).
} 
entre el amo y el esclavo, observada para el período colonial, posiblemente explique el desinterés de los amos por convertir a los esclavos, pues era un rito en el que se reconocía el carácter humano y, por ende, sacro de sus cuerpos, siendo un posible limitante de los actos de violencia irracional.

Ahora observemos cuáles son las implicaciones de esta postura paternalista en lo que respecta al castigo:

Que nos dice con esto, sino que sean las palabras del amo (...) con imporio (sic) y señorío, que al fin es amo; pero sean sus obras dulces, sus palos blandos, sus castigos nazca de un corazón limpio de culpa y blando, con mansedumbre. No veda el Espíritu Santo que no se reprenda, ni castigue; pero veda que se castigue y reprenda con exceso ${ }^{86}$.

De donde podemos deducir varias características del castigo físico: 1) era legítimo. Dada la menor capacidad intelectiva de los etíopes, no podían racionalizar sus faltas, de modo tal que era esencial recurrir a los golpes para castigar una acción; 2) no debía afectar de manera considerable la integridad física de los esclavos; 3 ) debía ser justificado, es decir, debía sancionar una acción específica y no darse por el simple capricho de los amos, y 4) era preventivo, en la medida en que buscaba interiorizar el error en los esclavos e impedir una acción similar futura. En términos generales, podemos caracterizar el castigo propuesto por Sandoval como correctivo y preventivo. Asimismo, este debe asemejarse más al castigo propinado por un padre con su hijo, que al dado, por ejemplo, a un animal.

\section{El esclavo}

Según Sandoval, el comportamiento de los esclavos debe ser siempre sumiso, pese a que los amos pudieran tener comportamientos erróneos:

Porque en esto consiste la gracia y amistad de Dios, y por este camino se alcanza, si el criado por conservar la conciencia pura con dios, y por deseo de agradarle, sufre con paciencia las tristezas y aflicciones, que injustamente le causan la furia de su señor $^{87}$.

Dentro de la lógica cristiana, el sufrimiento de los esclavos está asociado con la salvación del alma:

Porque vuestra vocación es para obedecer no solamente a los señores que os tratan [con] blandura, sino también a los que os tratan con aspereza y os agravian. Porque Cristo, dice, padeció por vosotros, dándoos ejemplo, para que sigáis sus pisadas ${ }^{88}$.

\footnotetext{
${ }^{86}$ Sandoval, Un tratado, 238.

${ }^{87}$ Ibídem, 234.

${ }^{88}$ Ibídem, 243-244.
} 
Como podemos observar, se asimilan los horrores de la esclavitud con los padecimientos de Cristo en la cruz. Sennet ${ }^{89}$ ha denominado esta elaboración del cuerpo divino próximo al humano la imitación de Cristo, donde la identificación de los creyentes supuso la divinización del cuerpo humano o la humanización del cuerpo divino y convirtió el Dios humanado en un modelo de conducta a seguir.

La crucifixión de Cristo debe ser entendida como un sacrificio ritual en el que se afirma la pertenencia total del ser humano a su origen divino y que implica el desprendimiento de los creyentes de lo corpóreo, de un bien material, terrenal y temporal, para congraciarse con el creador. En el caso de la crucifixión, Jesucristo puso en don -no un bien material externo, como eran los corderos en el Antiguo Testamento- su propio cuerpo, el cual fue lacerado, lastimado, degradado, para salvar el alma de la humanidad pecadora. Para Sandoval, la esclavitud y los maltratos físicos de los amos deben ser considerados, entonces, como sacrificios corporales por medio de los cuales los esclavos pueden enmendar la falta de su antecesor, Cam; es la llama que aviva sus ennegrecidos cuerpos y los transforma, para alcanzar, de esta manera, el paraíso.

En el caso de la esclavitud, se evidencian algunas de las tensiones constitutivas del cristianismo observadas por Dumont ${ }^{90}$. En tanto Cristo señaló que todos los seres humanos son iguales, esto solo es cierto en lo que Troeltsch ${ }^{91}$ denominó el individuo en relación con Dios. Es decir, en el plano espiritual, pues en el orden terreno Dios impuso un rígido orden jerárquico que debía ser respetado por todos los individuos. Como ha señalado Dumont: "el orden mundano es relativizado al estar subordinado a los valores absolutos: estamos ante una dicotomía ordenada. El individualismo extramundano implica reconocimiento y obediencia ante las potencias de este mundo",92.

Pese a que Dios había creado la igualdad, la esclavitud también había sido creada por él; es decir, los valores supremos extramundanos son relativos. Dicotomía que, como se puede observar, no trae como consecuencia una contradicción implícita en la práctica esclavista, puesto que los esclavos debían respetar los valores mundanos para obtener la salvación eterna.

Ahora bien, según Foucault ${ }^{93}$, aunque la pertenencia de los individuos a una iglesia significaba su inserción dentro de un poder pastoral -donde hacen parte de una

\footnotetext{
${ }^{89}$ Sennet, Carne y piedra.

${ }^{90}$ Louis Dumont, Ensayos sobre el individualismo (Madrid: Alianza, 1987).

${ }^{91}$ Troeltsch, The Social.

92 Dumont, Ensayos, 43.

${ }^{93}$ Michel Foucault, Historia de la sexualidad: la voluntad de saber (México: Siglo XXI, 1977), y Sujeto y poder (Bogotá: Carpe Diem, 1991).
} 
comunidad y están sujetos a una jerarquía-, los individuos debían buscar de manera personal la salvación del alma, según su libre albedrío y los preceptos cristianos. Es decir, el cristianismo supuso una forma de individuación del ser.

En tanto que los etíopes tenían cuerpo y alma espiritual, eran entes separados del amo y debían buscar la salvación por sus propios medios. Camino que estaba correlacionado con la esclavización y con la guía del amo, el cual, por su capacidad intelectiva, podía razonar y acceder a la verdad divina. Relación amo-esclavo de tipo suplementario, a diferencia de lo que se observó en el caso griego, donde el amo y el esclavo eran partes complementarias de una unidad orgánica.

\section{Conclusiones}

Pese a que diferentes argumentos teológicos de la legitimidad de la esclavitud se fundaron en la concepción aristotélica de esta como un sino natural e intrínseco a algunos seres humanos, el análisis discursivo a partir del cuerpo permitió observar algunas diferencias entre la argumentación de Aristóteles y la de Sandoval sobre la inferioridad de los esclavos.

Si bien la idea del cosmos en Grecia antigua establecía una jerarquía de los seres vivos basada en condiciones innatas de superioridad o inferioridad, la naturaleza no marcó de manera externa el cuerpo de los seres inferiores que podían y debían ser esclavizados. Sin embargo, la inexistencia del ejercicio político y del razonamiento de los pueblos bárbaros era un indicativo de su propensión natural hacia la esclavitud, lo que significaba que el mejor uso de su ser era como instrumento para la acción en la organización crematística del oikos.

El esclavo era considerado, de esta manera, una extensión corporal del amo, de la razón, cuyo desarrollo como ciudadano precisaba el desprendimiento de las preocupaciones terrenas. La relación amo-esclavo era de complementariedad, puesto que eran compuestos de una entidad orgánica indisoluble, cuya armonización para el mantenimiento de la comunidad del oikos y de la ciudad estaba mediada por la ritualidad y el acceso igualitario en la religión doméstica.

A diferencia de lo anterior, donde la inferioridad estaba contenida en el alma de los esclavos, en el caso de los pueblos etíopes, el color oscuro era el indicativo de su condición imperfecta pues era la marca de su descendencia de Cam, el siervo de siervos. No obstante esta inferioridad corporal, no es claro si para Sandoval era un indicativo suficiente de la esclavitud como una condición natural inherente al color de piel, aunque sí consideró que ella -la esclavitud-permitiría la conversión de los etíopes. La esclavitud, más que una condición, se construye como un mecanismo de adoctrinamiento ideal, en tanto que la incapacidad racional de los negros impedía que accedieran por sus propios medios a las verdades divinas. 
De manera similar a Aquino, para Sandoval hay una distinción entre el alma racional y el alma espiritual. De esta manera, pese a que los etíopes carecían de razón, al tener cuerpo y espíritu eran entes independientes del amo y debían buscar la salvación individual por sus propios medios. Ahora bien, como el conocimiento de Dios estaba mediado por la razón, el esclavo dependía de la guía del amo, quien debía ser el pastor que lo encauzara por el camino del bien. El amo, por lo tanto, no solo debía completar el proceso de conversión iniciado con el bautismo, también debía controlar las acciones y las conductas de los esclavos por medio del castigo físico y de una supervisión constante. Así se estructuró lo que Foucault ${ }^{94}$ denominó el poder pastoral.

Ahora bien, la supeditación del esclavo al amo debía ser consentida ${ }^{95}$ y el consentimiento se daba en el momento en que era bautizado y accedía a la comunidad de la Iglesia, donde los seres humanos hacían parte de una totalidad ordenada y jerarquizada que debía mantenerse y respetarse, pues articulaba los distintos componentes de la sociedad y, a su vez, estaba en concordancia con las determinaciones divinas.

El reconocimiento de la humanidad de los esclavos, así como su dependencia del amo, tanto por ser la guía racional y pastoral como por su superioridad dentro de la jerarquía comunitaria, introdujo una ruptura ontológica del ser, pues mientras en la antigua Grecia el amo y el esclavo eran una entidad indisoluble, para Sandoval el amo y el esclavo eran seres independientes, cuya relación era de tipo suplementario, y de ahí la moral cristiana no solo se correlacionó con unas normas de conducta de sujeción, sino que también legitimó la trata esclavista.

\section{Bibliografía}

Aristóteles. Acerca del alma. Madrid: Gredos, 1978.

Política. Bogotá: Imprenta Instituto Caro y Cuervo, 1989.

Ariza Montañés, Catalina. "Plantación adentro, camará: El cuerpo y las relaciones de poder en la hacienda de Tena. 1767-1805". Trabajo de grado en Antropología, Universidad Nacional de Colombia, Bogotá, 2005.

Aubin, Paul. El bautismo, ¿iniciativa de Dios o iniciativa del hombre? Santander: Editorial Sal Térrea, 1987. También obtenido de la red mundial el 19 de

${ }^{94}$ Foucault, Sujeto y poder.

${ }^{95}$ Término usado por Paguen, La caída del hombre. 
octubre de 2005, $\quad 9: 25 \quad$ horas.

$\mathrm{http} / / \mathrm{www}$.corazones.org/finalidaddelbautismo.com

Bajtin, Mijail. La cultura popular en la Edad Media y en el Renacimiento: el contexto de François Rabelais. Madrid: Alianza, 1990.

Balthasar, Hans Von. Gloria: una estética teológica. Madrid: Encuentro, 1986.

Bolaños, Álvaro Félix. Barbarie y canibalismo en la retórica colonial: los indios pijaos de fray Pedro Simón. Bogotá: Cerec, 1994.

Borja, Jaime Humberto. "Lo culto y lo salvaje: del fantasma del negro pagano al negro adoctrinado. Actitudes y tendencias de dos desterritorializaciones, $\mathrm{S}$. XVII”. Mecanografiado. Bogotá, 1991.

. Rostros y rastros del demonio en la Nueva Granada: indios, negros, judios y otras huestes de Satanás. Bogotá: Ariel, 1998.

Coulanges, Numa Denis Fustel de. La ciudad antigua: estudio sobre el culto, el derecho y las instituciones de Grecia y Roma. T. 1. Bogotá: Panamericana, 1996.

Castañeda, Felipe. El indio entre el bárbaro y el cristiano. Ensayos sobre filosofía de la conquista en Las Casas, Sepúlveda y Acosta. Bogotá: AlfaOmega; Universidad de los Andes, 2002.

Cruz, Juan. "Introducción”. En Cuestiones disputadas: sobre el alma, Tomás de Aquino. Pamplona: Editorial Universidad de Navarra, 1999.

Davis, David. El problema de la esclavitud en la cultura occidental. Bogotá: Áncora; Universidad de los Andes, 1996.

Dumont, Louis. Ensayos sobre el individualismo. Madrid: Alianza, 1987.

Finley, Moses. Esclavitud antigua e ideología moderna. Madrid: Crítica, 1982.

. La Grecia antigua: economía y sociedad. 1953; reimpresión, Barcelona: Crítica, 1984.

Foucault, Michel. Historia de la sexualidad: la voluntad de saber. México: Siglo XXI, 1977.

Sujeto y poder. Bogotá: Carpe Diem, 1991. 
García, Carlos y Aurelio Pérez. "Introducción”. En Política. Aristóteles. Madrid: Alianza, 2000.

Geertz, Cliford. La interpretación de las culturas. Barcelona: Gedisa, 2000.

González, Cristóbal. "Los metecos atenienses: un punto de vista sobre las clases sociales en la antigua Grecia". En Clases y lucha de clases en la antigua Grecia, Claude Mosse y otros. Madrid: Akal, 1977.

Le Bretón, David. La sociología del cuerpo. Buenos Aires: Nueva Visión, 2002.

Maya, Adriana. "Memorias en conflicto y paz en Colombia: la discriminación hacia lo(s) negro(s)". En Culturas y transformaciones sociales en tiempo de la globalización. Bogota: ICANH, 2003.

- Brujería y reconstrucción de identidades entre los africanos y sus descendientes en la Nueva Granada, siglo XVII. Bogotá: Ministerio de Cultura, 2005.

Martin, Alfred von. Sociología del Renacimiento. México: Fondo de Cultura Económica, 1976.

O'Gormann, Edmundo. La invención de América: Investigación acerca de la estructura histórica del Nuevo Mundo y del sentido de su devenir. México: Secretaría de Educación Pública, 1992.

Olsen, Margaret. Slavery and Salvation in Colonial Cartagena de Indias. Gainsville: University Press of Florida, 2004.

Pagden, Anthony. La caída del hombre natural: el indio americano y los orígenes de la etnología comparativa. Madrid: Alianza, 1988.

Phillips, William. La esclavitud de la época romana hasta inicios del comercio trasatlántico. Madrid: Siglo XXI, 1989.

Platón. Diálogos. T. 3. Bogotá: Talleres de Gráficas Modernas, 1994.

Sandoval, Alonso de. Un tratado sobre la esclavitud. 1627; reimpresión, Madrid: Alianza, 1987.

Saranyana, Josep-Ignasi. Breve historia de la filosofia medieval. Pamplona: Universidad de Navarra, 2001. 
Sennet, Richard. Carne y piedra: el cuerpo y la ciudad en la cultura occidental. Barcelona: Alianza, 1994.

Tardieu, Jean Pierre. "Du bonne usage de la monstruosite: la vision de l'Áfrique chez Alonso de Sandoval, (1627)". Bulletin Hispanique (Bordeaux, Francia), 86 (1984): 164-178.

Todorov, Tzvetan. La conquista de América: el problema del otro. México: Siglo XXI, 1999.

Troeltsch, Ernst. The Social Teaching of the Christian Churches. T. 1. Kentucky: Westminster-John Knox Press, 1992.

Vila Vilar, Enriqueta. "Introducción". En Un tratado sobre la esclavitud, Alonso de Sandoval. Madrid: Alianza, 1987.

Zabalza Iriarte, Joaquín. Lectura sobre el derecho: Tomás de Aquino y Latinoamérica. Bogotá: Universidad Santo Tomás de Aquino, 1978.

Fecha de recepción: 17 de mayo de 2005.

Fecha de aceptación: 23 de agosto de 2005. 